\title{
In Search of a Scapegoat: The Global Corporate Blame Game
}

\section{İnci Çinarli. Galatasaray University, Turkey}

\begin{abstract}
Humanity has a long tradition of searching for means to cope with crisis situations and to manage the order of society. In our contemporary world, corporations with their complex global networking often face crises and need to minimise damage. This paper aims to identify why and how scapegoating is used as a strategy in crisis communication by global business. To this end, Situational Crisis Communication Theory has been used to analyse some recent corporate crises (e.g. Volkswagen AG's handling of its emissions debacle and Costa Cruises' fatally shipwrecked Costa Concordia). This study reveals that, even though slightly different from its ancient counterparts in its aims, scapegoating is a frequent tool of corporations seeking to mitigate their multi-causal crises. It also appraises the efficacy of this manoeuvre.
\end{abstract}

Keywords: crisis management; crisis communication, scapegoating, public relations. 


\section{Introduction}

Crises undoubtedly are not specific to our century, but they became ubiquitous due to conventional media and especially the social media in the recent years. Crises occur almost every day in one corner of the world or even just beside us, and as a consequence; deaths, injuries, disabilities, loss of property and of reputation are being experienced.

Neoliberal capitalism and its globalisation transformed dramatically organizations, industrial relations, labour, social relationships, and crisis concept as one of the negative outcomes of this complex system. In this new phase of the capitalism or 'revised capitalism', where the governments are central to the modern capitalist system (McChesney, 1999) both corporate crises incidence has increased and identifying the crisis causality and managing the globalised corporations' global crises have became a remarkably difficult challenge. On the other hand, major crises of the $21^{\text {st }}$ century with severe global impacts (e.g. 2008 financial crisis, Enron, Volkswagen AG) have contributed in revising and reframing the responsibility of the organisations.

This article aims to identify the reasons and tactics in implementing 'scapegoating' strategies in the crisis communication process of the global business. To this end, Timothy Coombs' Situational Crisis Communication Theory (SCCT) has been used to analyse mainly two recent corporate crises: Volkswagen AG's handling of its emissions debacle and Costa Cruises' fatally shipwrecked Costa Concordia. These two corporate crises cases have not only a negative impact on their brand reputations, but have also a wider negative impact on industrial scale, and even on the nation brand, especially in VW case.

\section{Theoretical Framework and Methodology}

Prior to case study analyses, an interdisciplinary literature on the humanity's one of longest standing tradition of 'scapegoating' in the search of means to cope with crisis situations will be reviewed. After analysing the roots of this crisis communication strategy, two case study analyses will be conducted in order to identify why and how scapegoating is used as a strategy in crisis communication by global business. To this end, Coombs' 'Situational Crisis Communication Theory' (SCCT) will be used to analyse two crises case studies. 
The main limitation of this research is the epistemological ambiguity; as the facts discussed about the causality are being quoted from media coverage or from some expert comments/reports during the crisis reaction stage. This study does not aim to discuss the legal process and court verdicts at the post-crisis stage, therefore not to examine the fairness or unfairness of the blame; however to consider discussions about multi-causalities regarding to the crisis case. Furthermore, this article focuses on the implementation of the scapegoating strategy during a crisis communication process of a corporate crisis.

\section{Scapegoating Theories: Why Do We Need a Scapegoat?}

Scapegoating theory has rooted in religion, anthropology, and social psychology (Welch, 2006: 36). As philosophical anthropologist René Girard discusses in Violence and the Sacred (1988), scapegoating is all around us, in the tragedy literature masterpieces such as Sophocles' Oedipus the King, Euripides' The Bacchae, and Shakespeare's Julius Caesar, the rites and rituals of primitive people (Golsan, 2002: 38). Girard argues that scapegoat process is motivated by 'mimetic rivalry' and functions in the rhetorical catharsis. Within the 'mimetic theory', when a communal crisis or a 'sacrificial crisis' begins with mimetic contagion, someone is blamed arbitrarily as a scapegoat (Girard, 2013).

The word 'scapegoat' (fr. bouc émissaire) has its roots in myth and religious practices. In Greek, 'pharmakon' ( $\left(\alpha \operatorname{\alpha }_{\mu \alpha \kappa o v)}\right.$ is related to 'medicine, drug, and also poison', and therefore 'pharmakos' referred to "magical dose causing destruction or healing". It has been used as 'magic man, healer, and poisoner'. On one hand, the therapeutic meaning of 'pharmakos' referred to the medicine who heals the city, and on the other hand, to the poison (an excessively ugly or deformed man, a criminal or a slave) that had to be expelled from the system. In ancient Greece 'pharmakos' ( $\varphi \alpha \rho \mu \alpha \kappa o ́ \varsigma)$ was a ritual of scapegoat; a "human embodiment of evil who was expelled from the Greek city at moments of crisis and disaster", and pharmakoi ( $(\alpha \rho \mu \alpha \kappa o i)$ refers to scapegoats (Compton, 2006).

According to Concise Oxford Dictionary, the first meaning of 'scapegoat' refers to "a goat sent into the wilderness after the Jewish chief priest had symbolically laid the sins of the people upon it (Lev. 16)". The second meaning refers to "a person bearing the blame for the sins, shortcomings, etc. of others, especially as an expedient" (1995: 1231). The latter is being used in the everyday language in many cultures. Alongside the western culture, in the $17^{\text {th }}$ 
century Japan, monkey was believed as a scapegoat for a human victim of smallpox, and this believe has persisted for centuries. Ohnuki-Tierney indicates that the monkey's meaning as a scapegoat still continues in the contemporary Japan (1990: 137).

The English term '[e]scapegoat' was coined by William Tyndale for his 1530 translation of the Bible (Tyndale Bible), referring to the goat which was expelled on the Day of Atonement (Yom Kippur) (McLean, 1990: 168). Anthropologist Mary Douglas emphasises that the goat is not sacrificed, or the goat escapes from being killed as a sacrificial victim. Douglas points out that René Girard develops the idea that as slaughter is the main form of communication with the gods to a variety of persecutory behaviours, he uses the verb 'scapegoat' with a meaning of 'to persecute' or 'to blame' (2003: 121). On the other hand, in Leviticus 16: 8-10, and 16 there are references to sending scapegoats to Azazel (Satan) on Yom Kippur (Schwartz, 460). The ceremony requires two goats; one to be sacrificed and one released (Douglas; 2003: 122), which are carrying symbolically the sins of the Hebrews into exile:

"[...] and Aaron shall lay both his hands upon the head of the live goat and confess over him all the inequities of the people of Israel and all other transgressions, and all their sins, and he shall put them upon the head of goat and send him away into the wilderness... The goat shall bear all the iniquities upon him to a solitary land." (as cited in Welch, 2006: 36-37).

Therefore, a scapegoat is defined as a figure which represents social anxieties about social order. In order to avert the crisis a sacrificial victim, a scapegoat is found, who then becomes the focus of aggressive attention. Once the sacrifice has taken place, order is restored, and the community can go about its daily business as usual (Hetherington quoting Cohen, 2000: 15). In the mid-twentieth century, the term 'scapegoat' which real significance of sacrifice is at symbolic level, has been adapted in reference to those who are unfairly blamed for a social problem (Welch, 2006: 37). In communication studies, Kenneth Burke's (1945) theory of 'dramatism' comprises all rhetoric's sine qua non 'guilt-redemption' cycle or paradigm in which 'scapegoating mechanism' is one of the key elements. As for the psychological drivers of scapegoating; Burkean scapegoating mechanism aims at "self-purification by unburdening of one's sins ritualistically, with the goat as charismatic, as the chosen vessel of iniquity [...]" (1945: 301). On the other hand, the Freudian scapegoating can be described within the 'displacement' or 'projection' self-defence mechanism. Freud explains that people displace 
hostility they hold towards unacceptable targets onto less powerful ones. In the case of projection, unacceptable feelings and or anxieties denied within oneself might be attributed to others (Baumeister and Vohs, 2007: 778). Whereas Jungian scapegoating is a form of denying the 'shadow' (dark and unknown side of personality) both man and God (Perera, 1986: 9899).

\section{Scapegoating as a Crisis Communication Strategy}

Within crisis communication study which is a sub-area of public relations discipline; scapegoating is considered as a crisis reaction strategy used by organisations. The crisis concept has been identified as "a turning point for an organization" in the early crisis management literature (Fink, 1986:15), similarly as Regester (1989: 38) defines crisis as "turning points in organizational life". Pauchant and Mitroff indicate that crisis is "a disruption that physically affects the system as a whole and threatens its basic assumptions, its subjective sense of self, and its existential core" (1992: 15-16). Subsequent to these organization-centred definitions in the literature; the perception of the crisis by organization's publics/stakeholders and impact of the crisis upon them has been introduced to crisis definitions. In these later definitions, crisis concept has been defined as "the perception of low-probability, high-impact situation by critical stakeholders" (Pearson and Clair, 1998: 6061), "a major occurrence with a potentially negative outcome affecting the organization, company, or industry, as well as its publics, products, services, or good name" (Fearn-Banks, 2011: 2). And it has also been indicated that crisis "creates victims" (Lukaszewski, 2013: 10; 12).

When a crisis occurs, stakeholders and publics seek information on causality of the crisis in order to assign crisis responsibility. Along with many crisis definitions, crisis concept has also been identified as "an event for which people seeks causes and attributions" (Coombs and Holladay, 2004: 97). Public attributes responsibility to those who have been perceived as responsible of the crisis and therefore who are expected to manage the crisis.

Crisis management "is a process designed to prevent or lessen the damage a crisis can inflict on an organization and its stakeholders" (Coombs, 2014). Similarly, Fearn-Banks describes crisis management as "a strategic planning process that removes some of the risk and uncertainty from the negative occurrence and thereby allows the organization to be in greater 
control of its own destiny" (2011: 2). Hence, crisis management can be defined as a strategic process of achieving objectives to accomplish an ultimate goal, which is essentially to restore normalcy and survive the crisis with a minimal damage.

The core of the crisis management process is crisis communication. Fearn-Banks defines crisis communication as "the dialog that details strategies and tactics designed to minimize damage to the image of the organization" (2011:2). The communication demands of a crisis are "managing uncertainty, responding to the crisis, resolving it and learning from it" (Ulmer, Sellnow and Seeger, 2011: 73). Coombs states that crisis knowledge management and stakeholder reaction management are two types of crisis communication. Crisis knowledge management involves gathering information, processing this information into knowledge, sharing this knowledge with stakeholders and making decisions. As for stakeholder reaction management, it comprises communication efforts aiming to influence stakeholders' perceptions of the crisis management process (Coombs, 2012: 25).

'Corporate Apologia', 'Image Repair/Restoration Theory (IRT)', 'Situational Crisis Communication Theory (SCCT)', and 'Organizational Renewal Theory' are theoretical approaches for responding to organisational crises (Ulmer, Sellnow and Seeger, 2011: 15-16). These approaches present a chronological evolution.

'Scapegoating' is a crisis reaction strategy using by organisations during a crisis management process within the Situational Crisis Communication Theory (SCCT). Earlier version of this strategy is 'shift the blame', and has been developed within the Image Restoration Theory (IRT) by William Benoit (1995) and offers 14 potential crisis response strategies. Within this theoretical approach, an attack to an organisation has two components: (1) the accused is held responsible for an action; and (2) that act is considered offensive (Benoit, 1997: 178). The implementation of an effective response aims to repair the organisation's damaged image, therefore the reputation. 'Shift the blame' is one of the two forms of 'denial' strategies amongst the five major impression management strategies (the four others are evasion of responsibility, reducing the offensiveness of the event, corrective action, and mortification) (Ulmer, Sellnow and Seeger, 2011: 17), and the key characteristic is being introduced as 'act performed by another'. Hence, another person or organisation is being held responsible for 
the offensive act. The second 'denial' strategy is 'simple denial', and the key characteristic is being introduced as 'did not perform act' (Benoit, 1997: 179).

On the other hand, SCCT which has been developed by Timothy W. Coombs (1995) consists of a synthesis of Corporate Apologia, Impression Management, and Image Repair Theory (Ulmer, Sellnow and Seeger, 2011: 17). SCCT is based on the conceptualization of Bernard Weiner's Attribution Theory and rhetorical approaches to crisis communication articulated in IRT. According to the SCCT, stakeholders will make attributions about crisis responsibility which will affect stakeholders' interaction with the organisation in crisis (Coombs, 2012: 38). SCCT's strategic or text-oriented approach focuses on the description of the crisis, its impact, and on the crisis communication form and content (where, when, what, and how to say) (Frandsen and Johansen, 2007; Frandsen and Johansen, 2012).

At the first step SCCT groups three crisis categories: victim (low crisis responsibility/threat), accident (minimal crisis responsibility/threat), and intentional (strong attribution of crisis responsibility/threat). At the second step, SCCT aims to determine two intensifying factors: crisis history and prior reputation. Intensifiers increase the threat by increasing attributions of responsibility of the crisis. SCCT's crisis response strategies consist of three primary strategies (deny, diminish, rebuild), and one supplemental strategy (reinforcing) which subdivide in total of 10 crisis response strategies according to the SCCT cluster analysis study. 'Scapegoat' has been identified as a 'distance' strategy within the crisis is acknowledged while "weakening the linkage between the crisis and the organisation (or the person involved). One of the sub-categories of this strategy is 'excuse'. Excuse requires "minimizing the organization's responsibility for the crisis" through one of two tactics, i.e., denial of intention or denial of volition. Scapegoating is one form of denial of volition (Coombs, 1995: 451). The aim of this strategy is not very different from its ancient counterparts, which was to assign a 'vessel' to transfer "sins and blame".

\section{Case Study Analysis 1: Volkswagen AG Emission Scandal (Dieselgate)}

German vehicle maker Volkswagen AG comprises 12 brands which operate as an independent entity on the market including Volkswagen passenger cars, Audi, Seat, Skoda, Bentley, Bugatti, Lamborghini, Porsche, Ducati, Scania and Man. The Group operates 119 production plants in 20 European countries and a further 11 countries. Every weekday, 610,076 
employees worldwide produce nearly 42,000 vehicles selling in 153 countries (http://www.volkswagenag.com). In July 2015, Volkswagen AG has overtaken his Japanese rival Toyota in sales (Bowler, 2 October 2015). VW brand has been valued US\$31 billion making it the world's third most valuable auto brand prior to the crisis. It is estimated to have lost US\$10 billion in this value since the scandal has emerged (Brand Finance, n.d.). VW pretentious motto 'Das Auto' (eng. 'The Car') has been dropped as a part of showing the humility and image rebuild effort. Above and beyond Germany's iconic 'people's car's' (gr. volkswagen) seriously damaged reputation, Germany has lost its status as the world's most powerful nation brand to Singapore in 2015 and its nation brand value is down 4\% to US\$ 4,2 trillion (Brand Finance, 2015).

On September $18^{\text {th }}$, and later on November $2^{\text {nd }}$ of 2015 , the U.S. Environmental Protection Agency (EPA) issued notices of violation to Volkswagen AG, Audi AG, and Volkswagen Group of America, Inc. for allegedly installing defeat devices that circumvent EPA emissions tests in certain diesel cars (https://www.epa.gov/vw, May 2016). Worldwide, the software was uploaded in 11 million cars (500,000 vehicles in the U.S.). Therefore, this crisis belongs to the intentional crisis category of Coombs (strong crisis responsibility/threat). Beside the instructing information and care response, SCCT recommends adding compensation and/or apology strategies for crisis with strong attributions of crisis responsibility (Coombs, 2012: 42). Subsequent to the first EPA notice on September $20^{\text {th }}$, Prof. Martin Winterkorn, CEO of Volkswagen AG made a statement and admitted manipulations that violate American environmental standards, also took full responsibility. He expressed that he was 'personally deeply sorry'. On September 22, the President and CEO of Volkswagen US Group Michael Horn had admitted that company had "totally screwed up" in using software to manipulate emission tests (BBC News, 22 September 2015). At the third day of the crisis Winterkorn and Horn have resigned. Mathias Müller, Porsche former CEO who has replaced Winterkorn and Bernd Osterloh (Chairman of VW work's council and a member of executive committee) claimed at a press conference that the scandal was the result of "unlawful behaviour of engineers and technicians involved in engine development" and announced that a number of staff have been suspended. Osterloh's blame was as following: "A small group has done damage to our company. We need a climate where mistakes are not hidden" (The Guardian, 25 September 2015). 
At the Congressional subcommittee hearing on October $8^{\text {th }}$, Volkswagen U.S. Chief Executive Michael Horn admitted that defeat devices were fitted to Volkswagen's diesel automobiles as the company could not meet emissions standards. Horn blamed "couple of software engineers who put this in for whatever reason". He also added that according to his understanding, this was not a corporate decision, but rather it was something individuals did. VW has suspended more than 10 senior managers, including three top engineers, as part of an internal investigation. It has also hired a U.S. law firm to conduct an external inquiry (Reuters, 8 October 2015). On the other hand, German newspaper The Frankfurter Allgemeine Sonntagszeitung cited a source on VW's supervisory board who claimed the board with receiving an internal report at its recent meeting showing that VW technicians had warned about illegal emissions practices in 2011, but the company never addressed the warning (Cremer and Scherer, 27 September 2015).

VW has also admitted that diesel emissions tests in Europe were also manipulated and recalled millions of tainted diesel-powered cars (Boston, 28 January 2016). VW agreed in principle with the Department of Justice (Environmental Division), the EPA and CARB to fix or buy back 500,000 diesel cars equipped with illegal emissions software in US on April $21^{\text {st }}$ which cost was estimated at $\$ 7$ billion. The company is certain to face additional billions in fines and compensation paid to owners beyond the costs of repairs or buybacks in the U.S (Ewing, 21 April 2016). According to SCCT, compensation strategy is recommended for crises with low attribution of crisis responsibility and an intensifying factor or for crises with high attribution of crisis responsibility. Despite of Volkswagen AG's prior good reputation and no significant crisis history, the lack of clear information about the facts from the company might be considered as an intensifying factor. Although the crisis has not been resolved yet, the implementation of scapegoating strategy by the company at the crisis response stage can be evaluated as an attempt to restore the normalcy with a minimal damage. Hence, the scapegoating strategy provides a distraction from the 'whole picture' for a company in crisis. Even though an internal probe found no evidence of wrongdoing by members of senior management (Boston and Sloat, 11 May 2016), further research on the stakeholder attribution of responsibility needs as critics from VW's shareholders, workers, customers all around the world persist. 


\section{Case Study Analysis 2: Costa Concordia Shipwreck}

Carnival Corporation is a British-American global cruise company and one of the largest vacation companies in the world. The company deems itself as "the world's most popular cruise company" based on the number of guests (Arthur W. Page, n.d.: 4-5). Its vacation companies attract 10 million guests annually. Carnival Corporation's brands are: Carnival Cruise Line, Holland America Line, Princess Cruises, Seabourn, and Fathom in North America; P\&O Cruises and Cunard in the United Kingdom; AIDA Cruises in Germany; Costa Cruises in Southern Europe; and P\&O Cruises in Australia. Carnival Corporation owns more than 100 ships and (http://www.carnivalcorp.org). Each cruise line maintains separate sales, marketing, and reservation offices in accordance with brand autonomy (Arthur W. Page, n.d.: $5)$.

Previous to fatal Costa Concordia crisis, Carnival Corporation had few crises. In 2002, Carnival Corp. agreed to pay an $\$ 18$ million fine for environmental violations. In 2010, more than 3,000 passengers aboard the Carnival Splendor were towed to shore after an engine-room fire cut off the ship's electricity, but there were no injuries. Another ship, the Star Princess, caught fire in 2006 on its way to Jamaica; one person died and more than 10 were injured (Esterl and Lublin, 23 January 2012).

On the $13^{\text {th }}$ of January, at 19.33 (CET) cruise liner Costa Concordia was set sail from the Italian port Civitavecchia with 4,229 passengers and 1,023 crew and personnel on board for a seven days Mediterranean cruise. The ship struck a rock near Giglio Island, the collision resulted with a gash on the port-side. The compartments below the waterline flooded and the ship listed heavily to starboard. As a consequence, 32 people aboard lost their lives and more than 100 people injured. Costa Concordia disaster is the most expensive shipwreck in maritime history with costs exceeding US\$1 billion (Alexander, 2012: 5-7). This crisis belongs to accidental SCCT crisis category this crisis belongs to 'accident' (minimal crisis responsibility/threat) crisis category. But as it has been mentioned in the above paragraph, crisis history and prior reputation of Carnival Corporation could be evaluated as intensifying factors according to SCCT.

During his first interview to the media, Carnival's CEO Micky Arison expressed his sorrow and emphasised that this event was an accident as following: "When you have 100 ships out 
there, sometimes unfortunate things happen, but as I said, it was an accident. We as a company do everything we can to encourage the highest of safety standards" (NBC6, 9 March 2012). Arison's crisis response strategy is a 'justification' strategy according to the SCCT cluster analysis study. 'Justification' strategy is used during the crisis communication process in order to attempt to minimise the perceived damage caused by the crisis (Coombs, 2012: 36). Chaotic and disorganised evacuation with contradictory orders of the crew members revealed an ineffective, mismanaged crisis process. Costa CEO Pier Luigi Foschi who lead the crisis management "attributed the crew's lack of training to poor leadership of the ship's officers and language barrier" (Arthur W. Page, n.d: 6). Therefore, Foschi blamed the crew and used 'scapegoating' as a crisis communication strategy. Moreover, captain has also been sued by the company.

Captain Francesco Schettino has been accused by prosecutors of taking the liner too close to the shore and then abandoning ship with passengers and crew still on board. Schettino who has been under house arrest, told during his trial that he "wanted to kill three birds with one stone": to please the passengers, salute a retired captain on Giglio and do a favour to the vessel's head waiter who was a local. He has rejected rumours that he had wanted to impress his lover, Domnica Cemortan (BBC News, 11 February 2015). Schettino, claimed that he had informed corporate executives as soon as the accident happened and blamed bridge officers. Even though Schettino acknowledged some responsibility, he defended his decisions and claimed that he has been a 'scapegoat' as following: "All the responsibility has been loaded on to me with no respect for the truth or for the memory of the victims" he said (BBC, 11 February 2015).

Arison who stepped down as chief executive said: "You do wake up at night fearing certain things, because you've got 100 ships out there, stuff's gonna happen. And you'll have this nightmare scenario of, 'oh my god, the Titanic scenario', and you'll hope that ... you're prepared for every eventuality. But never in my wildest dreams did I ever imagine what Schettino did" (Blitz, 24 September 2013). Therefore, once again Carnival former CEO has blamed the captain.

LSE listed shares of Carnival Corporation stock dove nearly $20 \%$ on the $16^{\text {th }}$ of January and NYSE listed CCL stock dropped $14 \%$ on $17^{\text {th }}$ of January. Analysts warned on the financial 
impact of lost bookings, lost capacity, lawsuits, and industry-wide safety concerns (Arthur W. Page, n.d: 8). On $27^{\text {th }}$ of January Costa Cruises negotiated with Italian consumer groups and agreed on a compensation package of 14.500 \$ per passenger, a refund for the cruise, and reimbursement for all travel and medical expenses (Arthur W. Page, n.d: 22). Costa Cruises' lost revenues amounted to $€ 93$ million, the company has offered about $€ 50$ million in compensation to the surviving passengers, a class-action suit has been launched for $€ 350$ million (Alexander, 2012: 7). SCCT suggests the compensation strategy anytime when victims suffer serious harm (Coombs, 2012: 42).

Crash investigations revealed that the alarm system for the ship's computer navigation system was manually shut-off to conduct a salute and the ship was steered on a five mile diversion toward the island. Furthermore, 600 passengers who boarded in Rome had not participated in the evacuation drill prior to ship's cruising, the lack of backup power had resulted with total blackout, and watertight compartments had flooded (Arthur W. Page, n.d: 6). Similarly, Alexander analyses probable contributory causes of the disaster in three main category as (1) risk management, (2) planning, training and exercising, and (3) crisis management which represent interrelated factors involving the company and company's observance of maritime regulation (2013: 17-18). On the other hand, on July $20^{\text {th }} 2013$, Italian court has accepted plea bargains and has convicted five Costa Concordia employees (crisis coordinator, the ship's hotel director, two bridge officers, and a helmsman) of manslaughter and negligence with a prison sentence ranging from 18 months to two years and 10 months (Batty, 20 July 2013). As for Schettino, he was sentenced to 10 years for multiple manslaughters, five years for causing the shipwreck and one year for abandoning his passengers (BBC, 11 February 2015). This manoeuvre by the implementation of the scapegoating strategy overshadowed discussions about multi-causalities regarding the crisis and therefore corporate responsibility.

\section{Discussion and Conclusion}

Humanity has a long tradition of searching for means to cope with crisis situations and to manage the order of society. This study reveals that, even though slightly different from its ancient counterparts in its aims, scapegoating is a frequent tool of global corporations seeking to mitigate their multi-causal crises. Global corporations experiencing multi-causal crises within their complex global networking rather than admitting responsibility and endeavouring in order to prevent future crises rush into ascertain a 'scapegoat'. Responsibility avoiding and 
assigning a 'scapegoat' aim at reducing multi-causalities to a single one. This global corporate game is an efficient manoeuvre in order to manage a multi-causal crisis, as it provides a distraction from the 'whole picture'. Therefore, the scapegoat (pharmakoi) 'expelled' from the system serves as a 'healer' aiming at not managing the order of society as in ancient scapegoating rituals, but managing the sustainability of neoliberal system. 


\section{References}

Alexander, D. E. (2012) 'The 'Titanic Syndrome': Risk and Crisis Management on the Costa Concordia'. Journal of Homeland Security and Emergency Management, 9(1): 1-23.

Arthur W. Page Society (n.d.), 'Carnival Corporation: The Costa Concordia Crisis Case A and B'. Retrieved from http://www.awpagesociety.com/wpcontent/uploads/2013/03/Carnival-CorporationCase-A-and-B.pdf

BBC News (2015, 22 September). Volkswagen CEO: We totally screwed up. Retrieved from http://www.bbc.com/news/business-34323005,

BBC News (2013, 11 February), Costa Concordia captain Schettino guilty of manslaughter. Retrieved from http://www.bbc.com/news/world-europe-31430998

Batty, D. (2013, 20 July). Five Costa Concordia staff convicted over shipwreck in Italy, The Guardian, Retrieved from https://www.theguardian.com/world/2013/jul/20/five-costaconcordia-guilty-shipwreck-italy

Baumeister, R. F. and Vohs, K. D. (2007). Encyclopaedia of Social Psychology. Thousands Oak, California, CA: Sage.

Benoit, W. L. (1997). 'Image repair discourse and crisis communication'. Public Relations Review. 23(2): 177-186.

Blitz, R. (2013, 24 September). Chairman sees bright future for Carnival's Costa brand. Financial Times. Retrieved from http://www.ft.com/cms/s/0/df840308-2509-11e3bcf7-00144feab7de.html\#axzz4BNJAT2Hb

Boston, W. (2016, 28 January). Volkswagen begins recall of diesel cars in Europe. The Wall Street Journal. Retrieved from http://www.wsj.com/articles/volkswagen-begins-recallof-diesel-cars-in-europe-1453996552

Boston, W. and Sloat, S. (2016, 11 May). Volkswagen says emissions probe finds no wrongdoing by boards. The Wall Street Journal. Retrieved from http://www.wsj.com/articles/volkswagen-says-emissions-probe-finds-board-didntbreach-duty-1462974444

Bowler, T. (2015, 2 October). Volkswagen: from the Third Reich to emissions scandal, BBC News, Retrieved from http://www.bbc.com/news/business-34358783

Brand Finance (n.d.). VW risks its billion brand and Germany's national reputation, Retrieved from http://brandfinance.com/news/press-releases/vw-risks-its-31-billion-brand-andgermanys-national-reputation/ 
Brand Finance (2015, October). National Brands 2015. Retrieved from http://brandfinance.com/images/upload/brand_finance_nation_brands_2015.pdf

Burke, K. (1945). A Grammar of Motives. New York, NY: Prentice-Hall.

Carnival Corporation, Corporate information. Retrieved from http://www.carnivalcorp.org

Compton, T. M. (2006). Victim of the Muses: Poet as Scapegoat, Warrior and Hero in GrecoRoman and Indo-European Myth and History. Retrieved from http://nrs.harvard.edu/urn3:hul.ebook:CHS_Compton.Victim_of_the_Muses.2006

Concise Oxford Dictionary (1995). Della Thomson (ed.). $9^{\text {th }}$ edition. Oxford: Oxford University Press.

Coombs, T. W. (1995). 'Choosing the right words: The development of guidelines for the selection of the "appropriate" crisis response strategies". Management Communication Quarterly, 8: 447-476.

Coombs, Timothy W. (2012). 'Parameters for Crisis Communication'. In T. W. Coombs and S. J. Holladay (eds.). The Handbook of Crisis Communication (pp. 17-53). Massachusetts, MA: Blackwell.

Coombs, T. W. and Holladay, S. J. (2004). 'Reasoned action in crisis communication: An attribution theory-based approach to crisis management'. In D. P. Millar and R. L. Heath (eds.), Responding to Crisis Communication Approach to Crisis Communication (pp. 95-115). New Jersey, NJ: Lawrence Erlbaum.

Coombs, Timothy W. (2014, 23 April). 'Crisis management and communications'. Institute for Public Relations, http://www.instituteforpr.org/crisis-managementcommunications/

Cremer, A. and Scherer, S. (2015, 27 September). VW staff, supplier warned of emissions test cheating years ago: reports. Reuters, Retrieved from http://www.reuters.com/article/us-volkswagen-emissions-idUSKCNORP14U20150927

Cremer, A. (2016, 20 April). VW to pay each U.S. customer \$5,000 to settle dieselgate: Die Welt, Reuters, 20 April, http://www.reuters.com/article/us-volkswagen-emissionscourt-idUSKCNOXHOZV

Douglas, Mary (2003). 'The go-away goat'. In R. Rendtorff, R. A. Kugler and S. S. Bartlet (eds.). The Book of Leviticus: Composition and Reception (pp. 121-141). The Netherlands: Brill NV.

Environment Protection Agency, Volkswagen Violations, May 2016, Retrieved from https://www.epa.gov/vw 
Esterl, M. and Lublic, J. S. (2012, 23 January). Carnival CEO Lies Low After Wreck. The Wall Street Journal, Retrieved from http://www.wsj.com/articles/SB10001424052970204624204577177131752006116

Ewing, J. (2016, 21 April). Volkswagen reaches the deal in U.S. over emissions scandal, The New York Times. Retrieved from http://www.nytimes.com/2016/04/22/business/international/volkswagen-emissionssettlement.html?_r=0

Fearn-Banks, K. (2011). Crisis Communication: A Casebook Approach. $4^{\text {th }}$ ed. New York: Routledge.

Fink, S. (1986). Crisis Management: Planning for Inevitable. New York, NY: Amacom. Girard, R. (2013). Violence and the Sacred. P. Gregory (Trad.). London: Bloomsbury. Golsan, R. (2002). An Introduction: René Girard and Myth. New York, NY: Routledge. Hetherington, K. (2000). New Age Travellers: Vanloads of Uproarious Humanity. London: Cassell.

Lukaszewski, J. E. (2013). On Crisis Communication: What Your CEO Needs to Know About Reputation Risk and Crisis Management. Connecticut, CT: Rothstein Associates.

McChesney, R. W. (1999), 'Noam Chomsky and struggle against neoliberalism', Monthly Review Archives, 50, pp.40-47.

McLean, B. (1990). 'On the revision of scapegoat terminology'. Numen. 37(2): 168-173.

Ohnuki-Tierney, E. (1990), 'The monkey as self in Japanese culture'. In E. Ohnuki-Tierney (ed.). Culture Through Time: Anthropological Approaches (pp. 128-153). Stanford, California, CA: Stanford University Press.

Pauchan, T. and Mitroff, I. I. (1992). Transforming the Crisis-Prone Organization. California, CA: Jossey-Bass.

Perera, S. B. (1986). The Scapegoat Complex: Toward a Mythology of Shadow and Guilt. California, CA: Inner City Books.

Regester, M. (1989). Crisis Management: What to Do When the Unthinkable Happens. London: Hutchinson Business.

Reuters (2015, 8 October), Update 3: Volkswagen's US boss blames individuals for cheating. Retrieved from http://www.reuters.com/article/volkswagen-emissions-update-3-pix-tvgra-idUSL8N1281NL20151008 
Reuters (2016, 22 April). VW hikes emissions provisions to 16-17 billion euros: source.

Retrieved from ttp://www.reuters.com/article/us-volkswagen-emissions-provisionsidUSKCNOXJ0K3?mod=related\&channelName=businessNews

Ruddick, G. and Farrell, S. (2015, 25 September). VW: staff suspended as car giant appoints new CEO. The Guardian. Retrieved from https://www.theguardian.com/business/2015/sep/25/volkswagen-appoints-matthiasmuller-chief-executive-porsche-vw

Schwartz, H. (2004). Tree of Souls: The Mythology of Judaism. Oxford: Oxford University Press.

Taylor, E. and Wacket, M. (2016, 22 April). German carmakers to recall 630,000 cars to fix emissions: government official. Reuters. Retrieved from http://www.reuters.com/article/us-volkswagen-emissions-germany-probeidUSKCNOXJ19U?mod=related\&channelName=businessNews

Taylor, E. and Shepardson, D. (2016, 22 April). Daimler shares slide on U.S. emissions investigation. Reuters. Retrieved from http://www.reuters.com/article/us-daimleremissions-

idUSKCNOXJ0X0?feedType $=$ RSS\&feedName=businessNews\&utm_source=feedburn er\&utm_medium=feed\&utm_campaign=Feed\%3A+reuters\%2FbusinessNews+(Busin ess+News)

The Group, 31 December 2015, Retrieved from http: //www. volkswagenag.com

Ulmer, R. R., Sellnow, T. L. and Seeger, M. W. (2011). Effective Crisis Communication: Moving from Crisis to Opportunity. $2^{\text {nd }}$ ed. California, CA: Sage.

Welch, M. (2006). September $11^{\text {th }}$ : Hate Crimes and State Crimes in the War on Terror. New Jersey, NJ: Rutgers. 